INOBIS: Jurnal Inovasi Bisnis dan Manajemen Indonesia

Volume 1, Nomor 1, Desember 2017

Fani Firmansyah

\title{
Value Creation Strategy in Tourism : An Islamic Perspective
}

\author{
Fani Firmansyah \\ Doctorate Program in Management Science, Brawijaya University Malang. \\ firmansyahfani@yahoo.co.id
}

\begin{abstract}
The international tourism industry now is becoming an increasingly competitive marketplace. Understanding the needs, interests and behaviors of different tourist markets plays a critical role in support them to destinations. Given the fast growth in the number of tourists and despite the great Muslim population worldwide. It is important to develop appropriate marketing strategies. To develop tourism prospects sharia government could use such a marketing strategy, marketing for instance, marketing mix and segmenting, targeting and positioning (STP). The marketing mix is a set of marketing tools used by a state or a company to continue achieving its marketing objectives in target market. STP is the most important initial step in identifying customer value. It is expected from the use of this strategy could make sharia tourism as a market leader in the field of tourism and also could attract more tourists to visit and increase economic returns of state.
\end{abstract}

Keywords: Value, Strategic, Tourism, Management, Islamic, Marketing Mix

\section{Introduction}

Tourism is a field which gave a lot of contribution for economic growth. Tourism sector is a potential creative industry to be developed and can synergize with many other business sectors (Asih \& Asih, 2015). Tourism is a complicated concept that covers a wide range of social, behavioral, economic, political, cultural, and environmental considerations and consists of a set of activities, services, and benefits which all give tourists particular experiences (Namin, 2013). Tourism plays a key role in the economies of the four countries, although they exhibit contrasting stages of tourism and general development (Henderson, 2010).

The international tourism industry now is becoming an increasingly competitive marketplace. Understanding the needs, interests and behaviors of different tourist markets plays a critical role in attracting them to destinations. Muslims represent nearly $30 \%$ of the world population) and it has been predicted that their number will increase in the future. Muslims represent a large tourist niche market. Understanding Muslim tourists' needs and behaviors is vital for tourism businesses wishing to develop and promote products that suit this market.

Islam is one of the world's major religions and a powerful social force. Its influence extends to the domain of tourism where it can help to determine demand for travel among Muslims and the direction of their domestic and international tourist flows. The religion also affects formal tourism policymaking and industry operations in countries where state institutions and value systems are closely linked to Islam, or where there are significant numbers of Muslim citizens. (Henderson, 2010). The increased number of Muslims around the world has led to the formation of the Halal (religiously acceptable) concept, especially in Islamic countries. This concept has been successfully adopted in tourism. Despite the importance of the concept of destination branding in marketing, there are not many studies on 
INOBIS: Jurnal Inovasi Bisnis dan Manajemen Indonesia

Volume 1, Nomor 1, Desember 2017

\section{Fani Firmansyah}

destinations' Islamic brand, specifically, Muslims' evaluation of Islamic brand and the factors influencing this evaluation. It has been suggested that the effectiveness of destinations' brands can be examined from a customer (tourist) perspective through their five dimensions of awareness, image, quality, value and loyalty (Bianchi et al., 2014).

Islamic tourism focuses on such issues as engagement by Muslims, places (Islamic destinations), products (residential places, foods, and beverage), dimensions (economic, cultural, religious, etc), and managing service processes (marketing and ethical issues) (Henderson, 2010). In addition, creating value in Islamic tourism to attract and maintain tourists in Islamic societies, on one hand, and encouraging people of other countries to visit Islamic countries, on the other hand, require a thorough examination of motivations.

Sharia tourism is a new world trends, not only limited to religious tourism or pilgrimage tourism which has high potential business growth, but also believed able to increase the economics growth. Sharia tourism is one of tourism systems which its implementation based on sharia rules. The main concept of sharia tourism is a recreational activities with Islamic value for humanity and environment from the products or services, to make sure it's beneficial for all segmentation (Asih \& Asih, 2015). Religious tourism is motivated by religious or spiritual causes and also other motivations to tourism;. Islamic tourism is a form of religious tourism because tourists visit religious rituals, conferences, and ceremonies at national, regional, and international levels and in religious venues. Islamic tourism involves the abovementioned elements, it depends on other types of tourism such as social and economic tourism. Spiritual dimension is a solution to many social and personal problems. Religion affects social norms, customs, tradition, culture, and individual behaviors (Namin., 2013).

Although Islam is considered a major tourism market globally, however, special values of Muslims, who have particular needs in their system of beliefs, have not been well defined in the tourism market. In addition, unfortunately, many western countries have dedicated a considerable portion of their foreign exchange income and their scientific studies to this area while Muslim countries have been performing poorly in defining their roles and this has led to distorted views about Islam and Islamic values in non-Muslim countries (Henderson, 2010). Therefore, it seems that by the time the present study is conducted, research on Islamic tourism is still in its limited. The present theory attempts to present a teritical framework on how to create value in a Islamic perspective to tourism as new marketing strategy. Spiritual tourism has recently been accepted as a growing segment of tourism in business and research circles. The purpose of this paper is to suggest a new dimension in Islamic marketing and investigates spiritual tourism as a new strategy for marketing Islam as a religion.

\section{Literature Review}

\subsection{Tourism and Islamic Tourism}

Tourism plays a key role in the economies of the four countries, although they exhibit contrasting stages of tourism and general development. All marketing and product development effort that are directed at Muslims, even without completely religious motivations (Henderson, 2010). The verses of the Quran cited below from the chapters named in brackets endorse travelling with a view to achieving spiritual, physical and social goals. 
INOBIS: Jurnal Inovasi Bisnis dan Manajemen Indonesia

Volume 1, Nomor 1, Desember 2017

Fani Firmansyah

Al-Nahl (The Bee): 36;

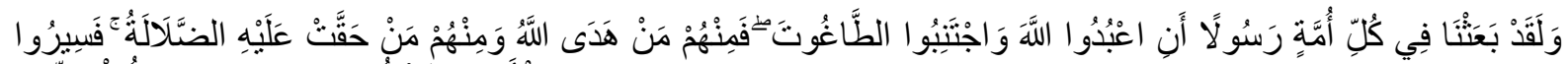

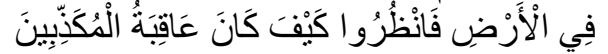

And We certainly sent into every nation a messenger, [saying], "Worship Allah and avoid Taghut." And among them were those whom Allah guided, and among them were those upon whom error was [deservedly] decreed. So proceed through the earth and observe how was the end of the deniers.

Al-'Ankaboot (The Spider): 20;

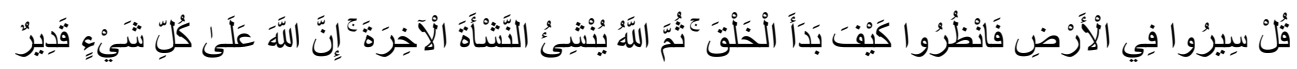

"Travel through the land and observe how He began creation. Then Allah will produce the final creation. Indeed Allah, over all things, is competent."

Al-Mulk (Kingship): 15

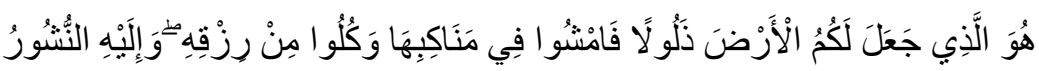

It is He who made the earth tame for you - so walk among its slopes and eat of His provision - and to Him is the resurrection.

(Yusuf Ali, 2005).

The lessons are more complete submission to God is possible through seeing firsthand the beauty and bounty of His creation; grasping the smallness of man reinforces the greatness of God. Travel can enhance health and well being, reducing stress and enabling Muslims to serve God better. It leads to the acquisition of knowledge and is a test of patience and perseverance. There is an overall consensus that growth is desirable, the pursuit of which is the responsibility of formal agencies whose existence and work suggests the importance attached to tourism.

Tourism through Muslims, although it can be extended to include non-believers (subject to compliance with Islamic values) (Shakiry, 2008). Islamic tourism in a sense of any activity, event, experience, or favor done at the destination in accordance with Islamic standards, alone or along with others, and in connection to visiting historical, artistic, and cultural sites, heritage, life style, economy, health, education, and other human interests. Din at Namin (2013) said that Islam regards traveling as a purposeful activity centered on motivations. Muslims go travel to achieve their physical, social, and spiritual goals (Sahih-Al Bukhari, 2011). Tourism is a meaningful activity originating from Islamic motivations. In this study, Islamic tourism refers to tourism by Muslims (Eid, 2013) or any activity, event, experience or indulgence undertaken in a state of travel that is compliant with Islam, to interface within an Islamic framework with one or all of the following: history, culture, arts, heritage, way of life, economy, health, education and any other human interests. Islamic tourism was created as a form of religious tourism because Muslims are motivated to visit religious ceremonies, conferences, functions and centers. Islamic tourism develops in 
INOBIS: Jurnal Inovasi Bisnis dan Manajemen Indonesia

Volume 1, Nomor 1, Desember 2017

\section{Fani Firmansyah}

destinations that provide opportunities for Muslims to practice their faith and follow the moral and religious laws of Islam.

Islamic tourism can be conceptualized from three different perspectives: economic; cultural; and religious (Al-Hamarneh and Steiner, 2004 \& Nassar. et al, 2015). An economic perspective, Islamic tourism assists the expansion of tourism within both Muslim and nonMuslim communities . A cultural perspective, Islamic tourism focuses on the provision of Islamic-friendly tourism programs, services and facilities and also introduces Islamic heritage sites to both Muslim and non-Muslim visitors. From a conservative religious perspective, Islamic tourism ensures that the tourism destination can fit the fundamental interpretation of the Islamic religion (Henderson, 2010).

Islamic tourism in the sense of a new moral dimension of tourism based on acceptable values and ethical and transcendental standard (Hassan, 2004). Din (1989) argues that Islam regards traveling as a purposeful activity centered on motivations. Muslims travel to achieve their physical, social, and spiritual goals (Sahih-Al Bukhari, 2011). Islamic tourism focuses on such issues as engagement, places (Islamic destinations), products (residential places, foods, and beverage), dimensions (economic, cultural, religious, etc), and managing service processes (marketing and ethical issues). Motivations and intentions are remarkably important in Islam, since they are related to attitudes and their outcomes (Henderson, 2010).

\subsection{Islamic Tourism as a Trade activity (Halal Tourism)}

The term "halal" means religiously acceptable and refer to those things that can be used by Muslims (Namin, 2015). It is halal to use or consume things that have not been prohibited by the Holy Quran or in Hadiths by Prophet. Therefore, a Muslim is expected to benefit from halals and to avoid harams product. In the area of consumer behavior, the decision making process used by consumers consists of four distinct steps (Kotler and Armstrong, 2011), consist of :

a. Motivations: involved in tourism activities generally include trading, visiting relatives and friends, performing physical activities (shopping), and having fun. Particular motivations for Muslims include doing good deeds for God, hajj and umrah, acknowledging man's insignificance compared to God, strengthening brotherhood among Muslims (Din, 1989), as well as trading, health and leisure, learning and acquiring knowledge, gaining information from scholars, knowing other cultures, promoting Islamic culture, learning from the past, etc.

b. Decision making: regarding Islamic tourism, true decisions are made based on Islamic principles which affect other steps of the decision making process.

c. Services: consumption of products includes emotional dimensions or pleasure, nonmaterial dimensions (spending time, efforts, and spirit), and quality of services

d. After-purchase assessment: includes perception of value, satisfaction, and behavioral attitudes (e.g. recommendations, complaints, and tendency to re-visit).. An important dimension of making purchasing decision is evaluation of product value.

Halal traveling and tourism is composed of three elements: (1) strengthening and promoting Islamic culture and values, (2) creating economic advantages for Muslim societies, (3) improving Islamic self-esteem, identity, and beliefs (Smith, 2011). 
INOBIS: Jurnal Inovasi Bisnis dan Manajemen Indonesia

Volume 1, Nomor 1, Desember 2017

Fani Firmansyah

\subsection{Features of Islamic Tourism}

Din (1989) classifies Islamic tourism as a purposeful tourism since tourists should pursue goals that are based on humanitarian principles. Tourists may also seek pleasure and giving thanks. The concept of Islamic tourism has the following properties Islamic tourism is flexible, reasonable, simple, and sensible. It is flexible since Islam calls people to visit places around the world. People can accompany their family members and friends to visit historical sites. Islam favors peace and encourages people to seek beauty in historical sites. Such activities reaffirm faith through giving thanks to the merciful God as the only creator of the world. Islam is a simple religion since it reveals what a man must do. Praying for five times during a day helps brining physical, emotional, and mental peace. This is also a symbol of giving thanks. In fact, praying is a natural treatment. While traveling, Muslims have to do the same things only in easier ways. For example, a traveler is not required to fast or to perform full prayer. Islam creates balance between two dimensions of life: traveling can strengthen connections between people and between men and God. Thus, tourism can lead to satisfaction from the world and the afterworld.

\subsection{Traveling Customs in Islam}

All religions, and particularly Islam, have identified a number of duties and ethical codes that should be followed by travelers. On the other hand, guests are recommended not to bother their hosts by prolonging their stay. Imam Ali (PBUH) had a poem about traveling: To obtain superiority, perfection, and virtue, set your feet out of your birthplace. Leave your town for foreign cities and find tour way to traveling and exploration There are five benefits to traveling which can be gained by leaving your hometown These five benefits are

a. Joy of traveling that helps you relieve sadness and pain. When someone is bound to stay in one place, their past and memories remind them of their problems and difficulties. When you leave your town, you leave all these pains behind. So the first benefit to traveling is to relieve pain and sadness. At least, human soul, which suffers from these pains, will be relieved temporarily and will experience joy.

b. Livelihood: a smart person can make money while traveling. One should not limit his thoughts to his surrounding environment. It is possible that someone reaches a better life in a new environment.

c. Knowledge: make money and acquire knowledge. Any knowledgeable person has a complete world. There may be knowledgeable persons in the town where you live. But other persons may have different forms of knowledge, although they may not have the same level of knowledge. When you meet another knowledgeable person, you learn new things and acquire new forms of knowledge. Traveling helps you improve your knowledge and gain more.

d. Customs and traditions: customs and traditions are not limited to those observed by the people of your town. You encounter other forms of customs and traditions when you travel to other places and you may find them better than yours. You learn new traditions and customs, compare them to your own, and improve your habits. In fact, traveling helps learning from new cultures and gives people more choices.

e. Company: another benefit of traveling, next to acquiring knowledge, is company. What does company mean? It means to have companion. While traveling, you may meet great men. Sometimes, this brings perfection to your soul. "To obtain superiority" means that you should not limit your goals to finding expensive hotels, 
INOBIS: Jurnal Inovasi Bisnis dan Manajemen Indonesia

Volume 1, Nomor 1, Desember 2017

\section{Fani Firmansyah}

best foods, excellent leisure places, and so on. A traveler accompanies great men of society and gains virtue.

\subsection{Value Assessment}

In value assessment, customers compare what they gained and advantages with what they gave (price and non-material costs) (Namin. 2013). In Islamic tourism, assessment is done in a quite different way. Based on Islamic needs. In other words, indecency, gambling, eating pork and other haram foods, drinking alcoholic beverages, and inappropriate clothing and makeup are prohibited. Muslims are expected to do their prayers in a clean place and to fast in Ramadan (Hashim et al, 2007). Therefore, Muslims' engagement in tourism activities is subject to receiving halal products, services, and environments. As such, Muslim and nonMuslim tourists can be identified based on their motivations in traveling and shopping, as shown in the above Figure 1:

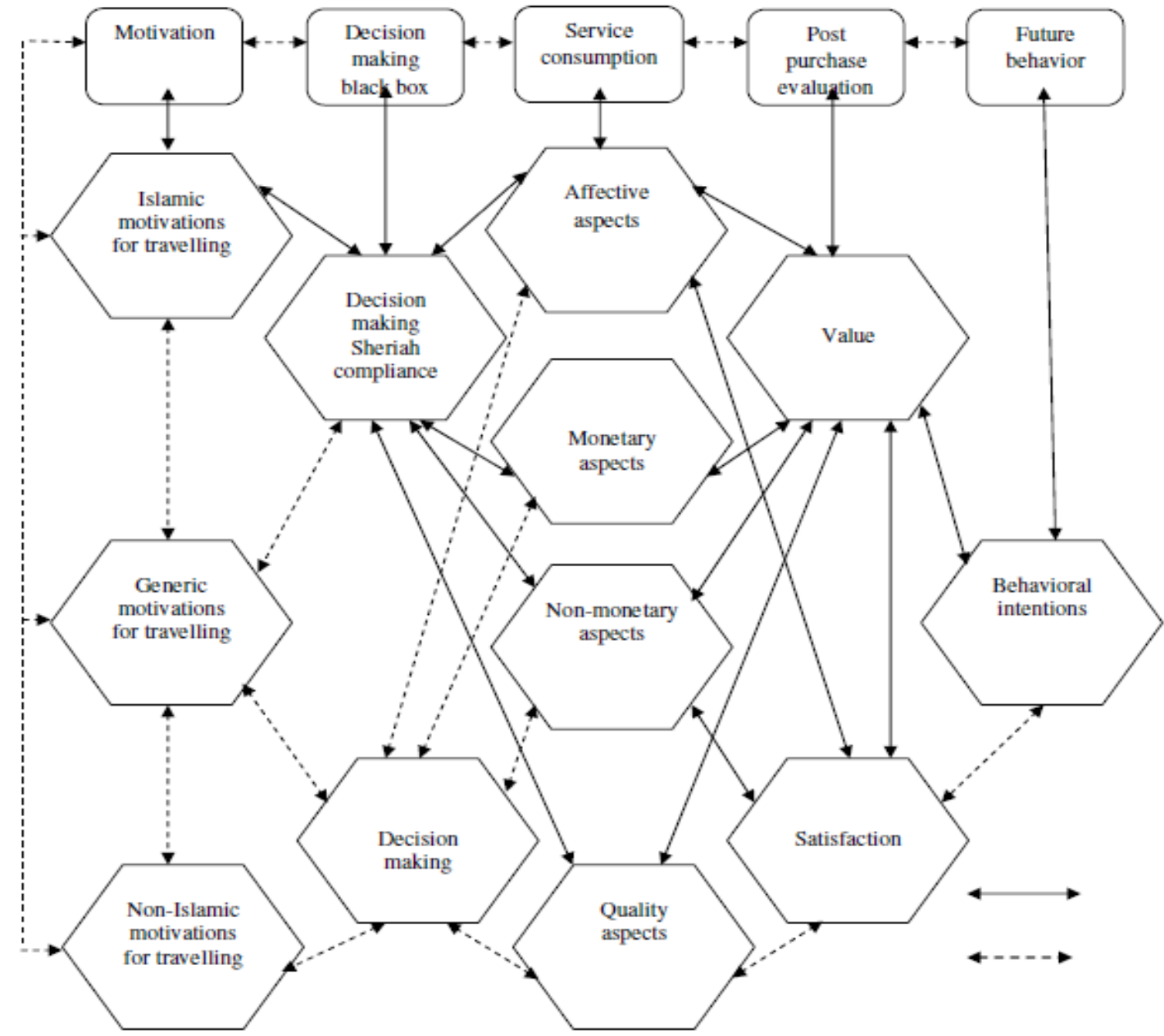

$\longleftrightarrow \quad$ Denots Tourism Participation and Evaluation Process for Non-Muslim Tourists

$\leftrightarrow$ Denots Tourism Participation and Evaluation Process for Muslim Tourists

Figure 1. A Model of Perceived Value for Islamic Tourism Decision Making Process 
INOBIS: Jurnal Inovasi Bisnis dan Manajemen Indonesia

Volume 1, Nomor 1, Desember 2017

\section{Fani Firmansyah}

The following phrases show how Islam attaches great value to traveling: It helps people reduce pressure and bring calm to their mind, body, and soul. A man can acquire knowledge and information through searching and thinking (Q Al Hajj : 46).

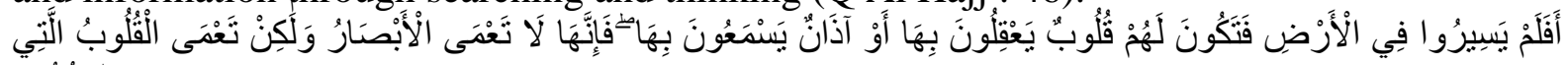
فِي الصنُدُورِ

So have they not traveled through the earth and have hearts by which to reason and ears by which to hear? For indeed, it is not eyes that are blinded, but blinded are the hearts which are within the breasts.

See the beauty of what God has created. In addition, God calls people to visit historical sites and learn from the mistakes made by the previous generations of mankind (Quran As Sadjah 32:26,

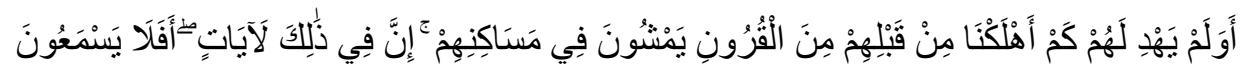

Has it not become clear to them how many generations We destroyed before them, [as] they walk among their dwellings? Indeed in that are signs; then do they not hear?

Islam considers travelling and exploration as a call, whether in words or deeds, for choosing the right path. Of course, one who calls for traveling should possess proper knowledge and behavior to communicate the correct Islamic message to societies.

\subsection{Hall Economy}

Now the fast growing halal economy provides all countries with big opportunities. Halal economy is a type of product in tourism which offers all services based on Islamic beliefs and deeds. This not only covers foods, but also production, processing, and distribution of products, additives, and elements. Halal economy also finds applications in medical equipment, cosmetics, and personal hygiene products. Henderson (2010) states that taking into account Islamic rules, hotels may rely on such rules as alcohol abstinence, having halal foods, having Quran and prayer devices at rooms, having no bed or toilet in Kiblah direction, having prayer room, having proper entertainments, having Muslim staff, Islamic clothing codes for staffs, separating leisure places for men and wo2men and also investments by Muslims.

\subsection{Tourism marketing : Influences And Determinants On Tourism Development}

To be fully successful tourism development involves the state, the private sector and the location's community since, at its simplest, tourism represents a temporary increase of the population of the destination chosen. The implications are that:

a. Planning for tourism is essential,

b. The system of planning differs fundamentally from the planning of other economic sectors, and

c. Tourism planning needs to be all-embracing, fully coordinated, undertaken over an extended time frame, and constantly monitored and adjusted on a rolling, iterative basis to take account of changing market conditions

A number of public and private tourism organisations have been aggressively marketing a variety of tourism products and services at nation al and international levels. Spiritual tourists are special interest tourists undertaking travel to achieve specific objectives 
INOBIS: Jurnal Inovasi Bisnis dan Manajemen Indonesia

Volume 1, Nomor 1, Desember 2017

\section{Fani Firmansyah}

with specific needs. Special interest tourism supplies tailored leisure and entertainment to cater for the particular desires of single or group tourists. It has been suggested that since services inherently have an intangible nature and they have intensive customer interaction, customer orientation plays a critical role in terms of commercial success for service organisations (Wagner et al., 2009). It is important to realise that product positioning is impacted by four critical factors: the tourist's emotional state at the place or destination, prior expectations of the place, the element of learning, and, satisfaction from travelling to the place. Positioning the spiritual tourism product using a market segmentation differentiation strategy is the most likely way to achieve a competitive advantage for business operators in the special interest tourism market (Dev et al., 2009). These factors recognised for effective market positioning guide this research towards identifying the major themes to use spiritual tourism for marketing Islam as discussed in the findings section.

Destination marketing is an essential tourism management tool that is employed to inform and infl uence tourist and industry attitudes and behaviour (Henderson, 2010) with attention concentrated on markets judged to be most profitable. To be able to develop sharia tourism, government should implement marketing strategies; STP and marketing mix, consist of (Asih \& Asih, 2915):

a. Segmenting of sharia tourism marketing

b. Geographic Segmentation:

c. Demographic Segmentation:

d. Age

Types of sharia tourism could be beneficial for every age circle whether from a baby to adult because an offered service is safe, comfortable and appropriate with shariah principle.

e. Members

Tourism sharia increasingly becomes a trending in the business world following the rapid of increasing in activity conducted tour of Muslim communities in various parts of the world. In such away, that sharia tour is suitable for the middle and upper economic society. It is because economic development in the Muslim-majority countries in the last decade that continues to grow and categorized as disposable income.

f. Targeting

The target are entire communities in Indonesia and abroad who are interested in nuances of Islamic tourism. Sharia tourism targeting strategy is to provide safe and comfortable facilities.

g. Positioning

Sharia tourism is expected becoming a leader market in tourism sector, in such away there is not only the banking sector which has implemented sharia system already but also the tourism sector. Marketing mix implementation in sharia tourism program development.

h. Product

Name of a service product is sharia tour, where the product could not just be beneficial to Muslims but also to all people in the world. This product also a continuation of the implementation of Islamic economics, as long as the Islamic economy continues to show good performance in economics. The provisions are based on Islam principles in order to support the economy of a state. 
INOBIS: Jurnal Inovasi Bisnis dan Manajemen Indonesia

Volume 1, Nomor 1, Desember 2017

Fani Firmansyah

i. Price

Most of people decide to choose tour destination would figure out the offered price from every tour and travel agents. In such away, the offered price should be appropriate with service quality given. A price is a important factor.

j. Place

Sharia tour is related with a place, the government in this aspect, before deciding to run tours of sharia, they must look first areas or places that could potentially be used as a tourist place of sharia. The area should have religious values, easily accessible and local wisdom occurred.

k. Promotion

In such away Indonesia could attract tourists both local and foreign, we should hold a promotion. Promotion is an activity to introduce a product that we manage to be well known and people will enjoy these products. Promotion could be done some steps, consist of:

- Oral promotion : Oral promotion is an announcement which relies on human, the information is directly delivered. People receive the information from others and re-deliver to other people.

- Website : Currently, there are a lot of service and product which is promoted by website or social media, as a sign of development of technology. Besides that, websites are easy to be accessed. Moreover the information given is clear

- Seminar. Presenting promotion with bigger scale could be done by holding a seminar. Seminar could be done by inviting students, legal party, society and could be done by countries which have good potentiality and expected that the participants could be interested in enjoying sharia tour.

- The relationship between nations. Both countries which have bilateral relations can promote countries that run sharia travel system.

1. People

To execute a plan should be supported by people. Therefore, to endorse the implementation of sharia tour and travel the government should improve the existing human resources in the country. One way in improving the quality of human resources is by training.

m. Process

Process is all the actual procedures, mechanisms and flow of activities that are used to deliver services. In this sharia tourism, implementation process should be in accordance with the principles of Islam in which there is no element of fraud, deception, confusion, excessive risk, corruption, manipulation, and usury.

n. Physical Evidence

Implementation of sharia tourism should pay attention to physical evidence for a real thing that influences the consumer's decision to purchase and use the product and services offered. The building could be made to resemble the magnificent mosque where the decor is equipped with a typical Indonesian ornament adapted to the values of beauty in Islam and not contrary to sharia.

\subsection{Quality Management}

Quality management for tourism is very important element in promoting tourism industry. Proper tourist attraction management should mobilize all available resources to attract tourists in the best possible way. Planning should be made in accordance with Islamic 
INOBIS: Jurnal Inovasi Bisnis dan Manajemen Indonesia

Volume 1, Nomor 1, Desember 2017

Fani Firmansyah

rules. Movement toward sustainable strategies is a must in Islamic tourism and should be achieved through consistent management and employing new ways of attracting tourists. For tourist destinations, relative advantages come from natural resources gifted by God including climate, landscapes, plants and vegetation, wild life, etc, while competitive advantages relate to how such resources are put into use in long term. International tourism environment brings about a number of obstacles that should be overcome by destinations that compete over tourists.

There are factors that affect success or competitive advantage of a destination at international level. These factors may lead to limitations on or management of competitive strength of a destination and involve ability to attract tourist, interaction between different elements, health and safety, promoting image, brands, and awareness, and creating trade names, costs, and values (Crouch and Ritchie, 1999). In addition, factors like demand for a destination (attractions and obstacles involved), management of destinations (management and marketing efforts), organizing abilities of destination, information system and research abilities, productivity and consistent experiences largely contribute to competitive advantage of a destination. It should be noted that destination management indicates a number of management processes that can increase attraction and demand for a destination. Supporting factors include infrastructures, access, facilities, hospitality, companies, etc. financial factors, marketing, marketing research, human resources, management of visitors and stakeholders are among the factors that contribute to qualification of a destination. Porter et al. (1990) enumerate factors like situational factors (e.g. personnel and infrastructures required for competitive advantage), demand factors (demand for goods and services), related and supporting industries, strategies, structure, and competition. Knowledge is the most important source of competitive advantage.

\subsection{Value Creation and Value Chain}

Successful organizations know that any business seeks creating value for customers, staffs, investors, and all persons involved in the process. Sustainable value cannot be created only for one group without regarding other groups. The focus here is on creating value for customers but this is not possible without having proper staffs or investors who regularly receive proper return on their investment. Value creation is a set of activities that increase the value of products and services even for several companies. Many of those involved focus on customers who buy their products and services and shareholders who wish to increase the value of their shares. The following Figure shows how this is done in an organization. 
INOBIS: Jurnal Inovasi Bisnis dan Manajemen Indonesia

Volume 1, Nomor 1, Desember 2017

Fani Firmansyah

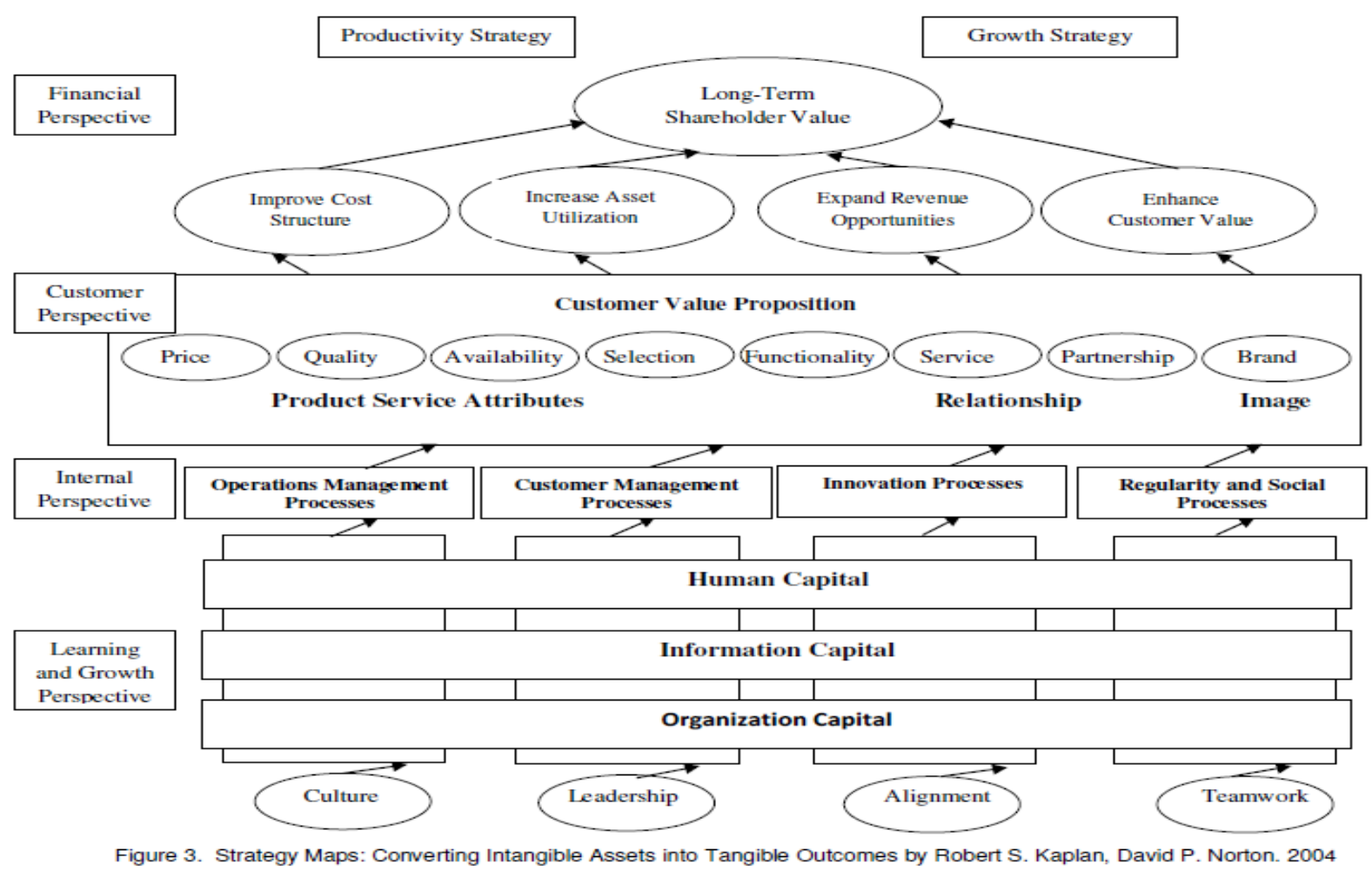

Value can lead to interaction between customers, goods, and services (Payne and Holt, 2001). Some consider a broader definition which includes non-financial costs, competence, marketing, and social factors. Others believe that value is a balance between what people perceive and what they should give to obtain something. Although it is difficult to define value, however, it is even more challenging to create value. Many value creators are the source of competitive advantage.

Individuals for whom travel is important, enjoyable and central to their lives are more likely to maintain consistency between their values and attitudes toward a destination of choice (Ferns and Walls, 2012). The more people are involved with their particular needs, the more they perceive the value of the destination attributes which fulfill those needs. Eid (2013) investigated the Muslim customers' perceived value (MCPV) and found that Muslim consumers assess products not only in functional terms of expected quality, price, emotional value and social value but also in terms of tangible attributes that result in the delivery of Sharia-compliant tourism products, such as Halal food and the availability of Shariacompatible art, fun and entertainment. These Islamic attributes include prayer facilities, Halal food, Islamic entertainments, Islamic dress codes, Islamic morality, open practice of religion and gender segregation. According to Jafari and Scott (2014), Muslims travel to particular sites due to their religious beliefs and attitudes, behaviors and perceptions, and perhaps, emotions at those sites are also under the influence of those beliefs and values. Porter (2003) states that value chain helps organizations analyze their particular activities to create value for customers and achieve competitive advantage. In his view, value creation for each organization is a goal in each strategy. Strategic balance between an organization and its environment to achieve competitive advantage has been emphasized by Porter. Other scholars believe that an outlook development should be emphasized for tourist destinations. Since maximizing benefits of economic growth, development, planning, and tourism strategies not only requires focus on demand and supply but also on value creation, therefore, 
INOBIS: Jurnal Inovasi Bisnis dan Manajemen Indonesia

Volume 1, Nomor 1, Desember 2017

Fani Firmansyah

accurate analysis and broad changes are needed for this purpose. Offering better tourism products requires identification of important resources, consist of environmental, industrial, and organizational resources and competition at national and international levels.

\section{Conclusion}

The way that should be implemented to develop sharia tourism is by coordinating government and business stakeholder to create Indonesia as world sharia tourism destination. The government must give a lot of attention and be optimistic that this business will develop rapidly, yield incomes, and creates a clean business environment. The society is also required to support the programs that will be conducted by the government and willing to be involved inside of the programs. The importance of developing tourism business are value and value creation in tourism. Value is created when advantages considered by customers, costs, and a combination of organizational activities to achieve these goals are identified. To create value, organizations should become consolidated and start creating value.

To improve tourist destinations in the Islamic world, it is necessary to pursue related goals based on Islamic principles and to manage such goals in a strategic way in order to provide competitive advantage in today's dynamic world. As such, it is necessary to meet Islamic tourists' expectations not only to provide tourists with desirable experience but also to protect the existing values and quality of life at destinations. As seen in the model below, there are interactions between all components of the model. In other words, success at national and international levels requires creating balance between destination goals and the existing elements used to create value in Islamic tourism in a consistent way in order to develop tourism.

\section{References}

A

Bukhari

2011. Retrieved from <http://www.searchtruth.com/book_display.php?book=1\&translator=1>, on 14 June 2011. Hadith translated by M. Muhsin Khan.

Al-Hamarneh, A. and Steiner, C. (2004), "Islamic tourism: rethinking the strategies of tourism development in the Arab world after September 11, 2001", Comparative Studies of South Asia, Africa and the Middle East, Vol. 24 No. 1, pp. 173-182.

Asih, Santi Mutiara and Sinta Kemala Asih. 2015. Marketing Strategy Implementation in Developing Sharia Tourism in Indonesia. International Proceedings of Management and Economy. IPEDR vol. 84 (2015) @ (2015) IACSIT Press, Singapore.

Bianchi, C., Pike, S.D. and Lings, I. (2014), "Investigating attitudes towards three South American destinations in an emerging long haul market using a model of consumerbased brand equity (CBBE)", Tourism Management, Vol. 42 No. 1, pp. 215-223.

Crouch GI, Ritchie JRB. 1999. "Tourism, Competitiveness and Societal Prosperity", Journal of Business Research, 44: 137-152.

Dev, C., Zhou, K.Z., Brown, J. and Agarwal, S. (2009), "Customer orientation or competitor orientation", Cornell Hospitality Quarterly, Vol. 50 No. 1, pp. 19-28.

Din K. 1989. Islam and tourism: Patterns, issues, and options. Annals of Tourism Research, $16,542-563$.

Eid, R. (2013), "Integrating Muslim customer perceived value, satisfaction, loyalty and retention in the tourism industry: an empirical study", International Journal of Tourism Research, Vol. 30 No. 8. 
INOBIS: Jurnal Inovasi Bisnis dan Manajemen Indonesia

Volume 1, Nomor 1, Desember 2017

\section{Fani Firmansyah}

Fern, B.H. and Walls, A. (2012), "Enduring travel involvement, destination brand equity, and travellers' visit intentions: a structural model analysis", Journal of Destination Marketing \& Management, Vol. 1. No. 1, pp. 27-35.

Hassan AR. 2004. Islamic tourism: The concept and the reality. Islamic Tourism, 14 (2).

Hashim NH, Murphy J, Hashim NM. 2007. Islam and online imagery on Malaysian tourist destination websites. Journal of Computer-Mediated Communication, 12, 1082-1102.

Henderson. Joan C..2010. "Chapter 6 Islam and tourism" In Tourism in the Muslim World. Published online: 08 Mar 2015; 75-89. Tourism in the Muslim World Bridging Tourism Theory and Practice, Volume 2, 75-89.

Jafari, J. and Scott, N. (2014), "Muslim world and its tourisms", Annals of Tourism Research, Vol. 44 No. 1, pp. 1-19.

Kotler P, Armstrong N. 2010. Principles of Marketing. 9 Th Ed. Upper Saddle River NJ: Pearson.

Mohamed A. Nassar Mohamed M Mostafa Yvette Reisinger , (2015),"Factors influencing travel to Islamic destinations: an empirical analysis of Kuwaiti nationals", International Journal of Culture, Tourism and Hospitality Research, Vol. 9 Iss 1 pp. 36 - 53

Namin AA, Tajzadeh. 2013. Value Creation in Tourism: An Islamic Approach. International Research Journal of Applied and Basic Sciences (C) 2013 Available online at www.irjabs.com. ISSN 2251-838X / Vol, 4 (0):0000. Science Explorer Publications.

Payne A, Holt S.2001. Diagnosing Custom Value: Integrating the Value Process and Relationship Marketing, British Journal of Management, 12:159-182., Retrieved August 30,2004m from Business Source Premier Database.

Porter ME.1990. The Competitive advantage of nations" London: Macmillan.

Shakiry AS. 2006. The academy of Islamic tourism project. Islamic Tourism, 25, SeptemberOctober. Retrieved from <http://www.itmitw. com/Articles/articles.php?issue $=25>$ on 23 June 2011.

Smith, C. (2007), "Working from the inside out: management and leadership through the lens of the perennial wisdom tradition", Journal of Management Development, Vol. 26 No. 5, pp. 475-83.

Wagner, T., Hennig-Thurau, T. and Rudolph, T. (2009), "Does customer demotion jeopardize loyalty?", Journal of Marketing, Vol. 73 No. 3, pp. 69-85. 